\title{
Analisis Perubahan Berat Badan, Indeks Massa Tubuh dan Persentase Lemak Tubuh Klien Pasca Pemberian Diet South Beach pada My Meal Catering Surabaya
}

\section{Analysis of Body Weight Change, Body Mass Index and Percentage of Body Fat Clients Post South Beach Diet at My Meal Catering Surabaya}

\author{
Ismi Faizah* ${ }^{1}$, Lailatul Muniroh ${ }^{1}$
}

\begin{abstract}
ABSTRAK
Latar Belakang: Obesitas merupakan masalah kesehatan yang bersifat global. Berbagai macam upaya yang dilakukan untuk mengontrol berat badan, salah satunya yaitu dengan mengatur pola makan. Diet south beach merupakan salah satu strategi dalam mengontrol berat badan dengan menerapkan pola makan dengan karbohidrat baik dan lemak baik.

Tujuan: Tujuan penelitian ini adalah menganalisis perubahan berat badan, indeks massa tubuh dan persentase lemak tubuh klien pasca pemberian diet south beach di My Meal Catering Surabaya.

Metode: Penelitian ini merupakan penelitian observasional longitudinal dengan sampel sebesar 30 orang. Pengumpulan data dilakukan dengan wawancara menggunakan kuisioner GPAQ untuk mendapatkan data aktivitas fisik dan form food recall $2 \times 24$ jam untuk melihat asupan makanan. Pengumpulan data meliputi berat badan, indeks massa tubuh dan persen lemak tubuh dilakukan dengan pengukuran menggunakan timbangan digital dan bioscan. Hasil yang didapatkan kemudian dibandingkan sebelum dengan sesudah pada hari ke 14 (fase 1) dan hari ke 28 (fase 2) menjalani diet south beach.

Hasil: Hasil penelitian menunjukkan bahwa rata-rata responden pada diet south beach fase 1 terjadi penurunan berat badan sebanyak $2,4 \mathrm{~kg}$, indeks massa tubuh sebesar $0,8 \mathrm{~kg} / \mathrm{m}^{2}$ dan persentase lemak tubuh sebanyak 1,3\%. Rata-rata responden pada diet south beach fase 2 terjadi penurunan berat badan sebanyak $1,4 \mathrm{~kg}$, indeks massa tubuh sebesar $0,5 \mathrm{~kg} / \mathrm{m}^{2}$ dan persentase lemak tubuh sebanyak $1,3 \%$.

Kesimpulan: Pemberian diet south beach dapat menurunkan berat badan, indeks massa tubuh dan persentase lemak tubuh klien. Responden diharapkan mampu mengenal pola makan sehat dan menerapkan dan mengadopsinya menjadi gaya hidup untuk seterusnya, tahap demi tahap.
\end{abstract}

Kata Kunci : diet south beach, berat badan, indeks massa tubuh, persentase lemak tubuh 


\section{ABSTRACT}

Background: Obesity is a global health problem. Various attempts are made to control weight, one of which is by adjusting the diet. South beach diet is one of the strategies in weight control. South beach diet applies a diet with good carbohydrate and good fats.

Objectives: The purpose of this study was to analyze body weight change, body mass index and body fat percentage of clients post south beach diet in My Meal Catering Surabaya.

Methods: This research is a longitudinal observational study with a sample size of 30 clients My Meal Catering. Data was collected by interview using a questionnaire GPAQ to obtain data of physical activity and form food recall for 48 ours. Data collection includes BW, BMI and BFP carried out by measurement using digital scales and bio scan. The results obtained are then compared before and after south beach diet on day 14 (phase 1) and 28 (phase 2).

Results: The results showed that the average respondents on south beach diet phase 1 weight loss of $2.4 \mathrm{~kg}$, body mass index of $0.8 \mathrm{~kg} / \mathrm{m}^{2}$ and body fat percentage of $1.3 \%$. The average respondents on south beach diet phase 2 lost weight $1.4 \mathrm{~kg}$, body mass index of $0.5 \mathrm{~kg} / \mathrm{m}^{2}$ and body fat percentage of $1.3 \%$.

Conclusions: South beach diet affects lose body weight, body mass index and body fat percentage change of My Meal Catering clients. Respondents are expected to be familiar with a healthy diet and apply then adopt it into a lifestyle for the next, step by step.

Keywords: south beach diet, body weight, body mass index, body fat percentage

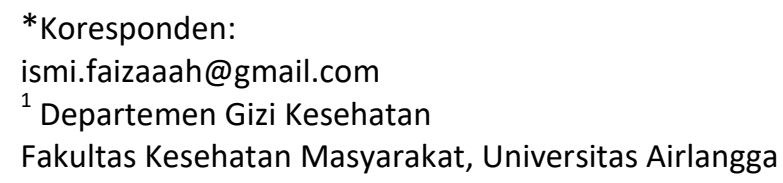

\section{PENDAHULUAN}

Obesitas merupakan salah satu masalah kesehatan bersifat global dan terus berkembang serta dapat mempengaruhi derajat kesehatan di berbagai negara. Obesitas pada umumnya berkaitan erat dengan pola makan yang tidak baik dan cenderung kelebihan energi ${ }^{1}$. Obesitas didefinisikan sebagai suatu kondisi medis berupa akumulasi lemak dalam tubuh yang secara klinis dinyatakan dalam bentuk Indeks Massa Tubuh (IMT) $\geq 27 \mathrm{~kg} / \mathrm{m}^{2}{ }^{2}$. Berbagai faktor menjadi penyebab dari terjadinya obesitas baik dari internal maupun eksternal seperti genetik, gangguan metabolisme, ketidakseimbangan energi dan aktivitas fisik. Apabila tidak ditangani dini, obesitas dapat menyebabkan osteoarthritis, kanker, penyakit jantung koroner (PJK) dan gangguan pernapasan seperti sleep apnea ${ }^{3}$.

Prevalensi obesitas pada dewasa di kota Surabaya pada tahun 2015 menunjukkan angka $82,81 \%^{4}$. Angka kejadian obesitas tersebut mengalami peningkatan apabila dibandingkan dengan tahun 2014 yakni $48,32 \%^{5}$. Penatalaksanaan obesitas antara lain yakni bertujuan untuk menurunkan berat badan sehingga dapat mencegah komplikasi dan gejala klinis akibat obesitas ${ }^{6}$.

Diet south beach merupakan salah satu strategi yang dapat membantu dalam menurunkan berat badan. Diet ini adalah diet yang diterapkan di My Meal Catering Surabaya dan paling banyak diminati apabila dibandingkan dengan diet penurunan berat badan yang lain seperti atkins dan food combaining. Diet ini menerapkan pola makan dengan karbohidrat baik dan lemak baik. Karbohdirat baik yang dimaksud yakni karbohidrat kompleks dan tinggi serat. Lemak tak jenuh disebut dengan lemak baik. Diet south beach ini juga membantu dalam peningkatan kualitas kimia darah dan mengurangi berat badan sehingga dapat terhindar dari penyakit jantung dan 
kardiovaskuler yang disebabkan obesitas ${ }^{7}$. Diet south beach ini diterapkan berdasarkan tiga fase. Prinsip dari masing-masing fase yakni fase 1 tidak menyajikan karbohidrat seperti nasi, kentang dan cenderung tinggi serat dan tinggi protein. Fase 2 mulai mengonsumsi karbohidrat baik dengan memperhatikan indeks glikemik seperti nasi merah dan kentang panggang. Fase 3 mulai mengonsumsi makanan secara beragam. Pola makan diet south beach dapat menurunkan berat badan antara 4-7 kg dalam 2 minggu pertama ${ }^{7}$. Penelitian sebelumnya menunjukkan terjadinya penurunan berat badan 7,2 kg setelah menjalani diet south beach selama 3 minggu $^{8}$. Efek samping individu yang menjalani diet ini yakni dehidrasi, sakit kepala, konstipasi, hipoglikemia dan kekurangan vitamin ${ }^{9}$.

Apabila ditinjau dari prinsip diet, penerapan diet south beach ini cenderung konsumsi makan dengan prinsip rendah karbohidrat. Apabila dibandingkan gizi seimbang, diet ini tidak menyediakan karbohidrat pada fase 1 dan penyediaan karbohidrat tidak beragam pada fase 2 . Buah dan sayur yang disajikan juga tidak beragam. Kalori yang disajikan diet south beach ini berbeda-beda setiap fasenya. Penelitian Ramadhani menyebutkan bahwa terdapat penurunan berat badan (BB), indeks massa tubuh (IMT) dan persentase lemak tubuh (PLT) setelah pemberian diet rendah karbohidrat selama dua minggu ${ }^{10}$. Namun penurunan berat badan (BB), indeks massa tubuh (IMT) dan persentase lemak tubuh (PLT) juga dapat dipengaruhi oleh beberapa faktor lainnya seperti usia, jenis kelamin dan aktivitas fisik.

Berdasarkan latar belakang diatas, diet south beach dapat membantu mengontrol berat badan. Maka diperlukan adanya penelitian untuk mengetahui pengaruh diet south beach terhadap perubahan berat badan, indeks massa tubuh dan persentase lemak tubuh. Tujuan penelitian adalah menganalisis perubahan berat badan, indeks massa tubuh dan persentase lemak tubuh klien pasca pemberian diet south beach di My Meal Catering Surabaya. Penelitian ini diharapkan bermanfaat bagi responden sebagai informasi untuk mengenal dan memahami bahwa pola makan yang benar dapat bermanfaat untuk menjaga berat badan. Penelitian ini juga diharapkan dapat bermanfaat bagi pembaca sebagai informasi, pengetahuan, meningkatkan wawasan terkait diet south beach.

\section{METODE}

Penelitian ini merupakan jenis penelitian observasional longitudinal. Populasi dalam penelitian ini yakni sebanyak 30 orang per dua bulan. Sampel dalam penelitian ini diambil berdasarkan studi populasi yakni sebanyak 30 klien My Meal Catering dengan kriteria inklusi klien telah mengikuti program diet south beach tidak melebihi 10 hari. Variabel dalam penelitian ini dibagi menjadi tiga yaitu variabel independen terdiri dari diet south beach, variabel dependen yaitu terdiri dari berat badan (BB), indeks massa tubuh (IMT) dan persentase lemak tubuh (PLT) sedangkan variabel perancu yaitu aktivitas fisik dan asupan energi. Durasi penerapan diet fase 1 maupun fase 2 masingmasing 14 hari.

Karakteristik yang digali dalam penelitian ini terdiri dari jenis kelamin, usia, pendidikan, aktivitas fisik dan asupan energi. Data yang dikumpulkan yaitu data primer dan data sekunder. Data primer diperoleh dari hasil wawancara dengan kuesioner terkait aktivitas fisik menggunakan kuisioner GPAQ (Global Physical Activity Questionnaire) yang dikembangkan oleh WHO 2010 dan asupan makanan menggunakan form food recall $2 \times 24$ jam. Selain itu, dilakukan pengukuran berat badan menggunakan timbangan digital dengan merk GEA dan ketelitian $0,1 \mathrm{~kg}$, untuk kemudian didapatkan hasil indeks massa tubuh. Persentase lemak tubuh yang diukur menggunakan bioscan dengan merk maltron. Data sekunder meliputi berat badan, indeks massa tubuh dan persentase lemak tubuh sebelum mengikuti program diet south beach didapatkan melalui data yang terdapat pada instansi yakni my meal catering.

Setelah menjalankan program diet pada hari ke 14 (fase 1) dan 28 (fase 2) lalu dilakukan pengukuran berat badan, indeks massa tubuh dan persen lemak tubuh. Hasil tersebut nantinya akan dibandingkan antara sebelum diet dengan hari ke 14 (fase 1) dan 
hari ke 28 (fase 2) dibandingkan dengan hari ke 14 (fase 1). Recall 2x24 jam dengan masingmasing dilakukan recall satu kali pada setiap fase, kemudian asupan energi dan zat gizi makro dibandingkan dengan angka kecukupan gizi yaitu dinyatakan inadekuat jika $<77 \%$ AKG dan kategori adekuat $\geq 77 \% A K \mathrm{AG}^{11}$. Hasil dari penelitian ini dianalisis menggunakan analisis univariat. Analisis univariat dilakukan untuk distribusi frekuensi dari karakteristik usia, jenis kelamin, pendidikan dan aktivitas fisik dan asupan makanan. Selain itu, juga menggunakan analisis perubahan berat badan, indeks massa tubuh dan persentase lemak tubuh. Penelitian ini telah lulus etik oleh Komisi Etik Fakultas Kesehatan Masyarakat Universitas Airlangga Surabaya dengan sertifikat etik no 419-KEPK pada tanggal 26 Juli 2017.

\section{HASIL DAN PEMBAHASAN}

Dalam penyediaan makanan, total energi yang disediakan oleh my meal catering dapat dibedakan berdasarkan fasenya. Pada fase 1 disediakan sekitar $900 \mathrm{kkal}$ dan fase 2 disediakan sekitar 1200-1500 kkal. Kalori didapatkan dari makan pagi, makan siang, makan malam dan dua kali selingan. Kalori diet south beach yang disajikan oleh My Meal Catering tidak sesuai dengan anjuran diet rendah kalori bahwa program penurunan berat badan dilakukan melalui gizi seimbang dengan melakukan pengurangan kalori sebesar 500-1000 kkal/hari ${ }^{12}$. Diet rendah kalori dapat memiliki efek samping dehidrasi, sakit kepala, konstipasi, hipoglikemia dan kekurangan vitamin ${ }^{9}$.

Diet south beach ini menerapkan makan dengan karbohidrat dan lemak baik. Karbohidrat baik yakni karbohdirat kompleks seperti nasi beras merah dan kentang yang dipanggang. Lemak baik yakni lemak tak jenuh, bahan makanan yang dipilih rendah lemak seperti ayam tanpa kulit dan berlemak baik seperti menggunakan minyak kanola atau minyak zaitun dalam mengelolah makanan ${ }^{7}$.

Karakteristik responden Tabel 1 menunjukkan bahwa sebagian besar responden dalam penelitian ini berjenis kelamin perempuan yaitu $56,7 \%$. Hal tersebut disebabkan body image atau citra tubuh seringkali dikaitkan dengan wanita dibandingkan pria, karena perempuan cenderung lebih memperhatikan penampilannya $^{13}$. Sejumlah $40 \%$ responden berusia 26-35 tahun tergolong dalam kategori dewasa awal. Pada usia tersebut seseorang mulai mencapai puncak karir serta secara fisiologis metabolisme mulai melambat akibat

Tabel 1. Distribusi Karakteristik Responden My Meal Catering Surabaya

\begin{tabular}{lcc}
\hline \multicolumn{1}{c}{ Karakteristik } & $\mathbf{n ~ ( 3 0 )}$ & $\mathbf{\%}$ \\
\hline Jenis Kelamin Responden & & \\
Pria & 13 & 43,3 \\
Wanita & 17 & 56,7 \\
\hline Usia Responden (tahun) & & \\
Remaja Awal (12-16) & 2 & 6,7 \\
Remaja Akhir (17-25) & 1 & 3,3 \\
Dewasa Awal (26-35) & 12 & 40 \\
Dewasa Akhir (36-45) & 6 & 20 \\
Lansia Awal (46-55) & 5 & 16,7 \\
Lansia Akhir (56-65) & 3 & 10 \\
Manula (>65) & 1 & 3,3 \\
\hline Tingkat Pendidikan & & \\
Tamat SD & 2 & 6,7 \\
Tamat SMP & 0 & 0 \\
Tamat SMA & 0 & 0 \\
Tamat PT & 28 & 93,3 \\
\hline Aktivitas Fisik Responden & & \\
Ringan & 20 & 66,6 \\
Sedang & 8 & 26,6 \\
Berat & 2 & 6,6 \\
\hline
\end{tabular}

Tabel 2. Total Energi dan Zat Gizi Makro Responden Diet South Beach Fase 1 dan Fase 2

\begin{tabular}{lcc}
\hline \multicolumn{1}{c}{ Variabel } & $\begin{array}{c}\text { Median } \pm \\
\text { SD (Fase 1) }\end{array}$ & $\begin{array}{c}\text { Median } \\
\text { (Fase 2) }\end{array}$ \\
\hline $\begin{array}{l}\text { Energi } \\
\text { (kkal/hari) }\end{array}$ & $1058 \pm$ & $1413 \pm 186,4$ \\
$\begin{array}{l}\text { Karbohidrat } \\
\text { (gr/hari) }\end{array}$ & 146,7 & \\
$\begin{array}{l}\text { Protein } \\
\text { (gr/hari) }\end{array}$ & $68,5 \pm 4,8$ & $132 \pm 7,2$ \\
$\begin{array}{l}\text { Lemak } \\
\text { (gr/hari) }\end{array}$ & $42 \pm 4,7$ & $41 \pm 6,6$ \\
\hline
\end{tabular}


Tabel 3. Perubahan Indeks Massa Tubuh dan Persentase Lemak Tubuh Pasca Diet South Beach

\begin{tabular}{lcccccc}
\hline \multirow{2}{*}{ Variabel } & \multicolumn{2}{c}{ Sebelum Diet } & \multicolumn{2}{c}{ Fase 1 } & \multicolumn{2}{c}{ Fase 2 } \\
\cline { 2 - 7 } & $\mathbf{n}$ & $\mathbf{\%}$ & $\mathbf{n}$ & $\mathbf{\%}$ & $\mathbf{n}$ & $\mathbf{\%}$ \\
\hline IMT & & & & & & \\
$\quad$ Normal & 2 & 6,66 & 3 & 10 & 4 & 13,3 \\
$\quad$ Overweight & 9 & 30 & 9 & 30 & 10 & 33,3 \\
$\quad$ Obesitas & 19 & 63,3 & 18 & 60 & 16 & 53,3 \\
\hline PLT & & & & & & \\
$\quad$ Obesitas & 20 & 66,6 & 19 & 63,3 & 14 & 46,6 \\
$\quad$ Tidak Obesitas & 10 & 33,3 & 11 & 36,6 & 16 & 53,3 \\
\hline
\end{tabular}

Tabel 4. BB, IMT dan PLT Sebelum dan Sesudah Diet South Beach pada Responden

\begin{tabular}{|c|c|c|c|c|c|c|}
\hline Variabel & $\mathrm{n}$ & $\begin{array}{c}\text { Sebelum Diet } \\
\text { Mean } \pm \text { SD }\end{array}$ & $\begin{array}{c}\text { Sesudah Diet } \\
\text { hari ke } 14 \\
\text { Mean } \pm \text { SD }\end{array}$ & $\begin{array}{c}\text { Sesudah Diet } \\
\text { hari ke } 28 \\
\text { Mean } \pm \text { SD }\end{array}$ & $\begin{array}{l}\text { Selisih hari } \\
0-14\end{array}$ & $\begin{array}{c}\text { Selisih hari } \\
14-28\end{array}$ \\
\hline BB (kg) & 30 & $80,4 \pm 18$ & $78 \pm 17$ & $76,6 \pm 16,2$ & $2,4 \mathrm{~kg}$ & $1,4 \mathrm{~kg}$ \\
\hline $\begin{array}{l}\mathrm{IMT} \\
\left(\mathrm{kg} / \mathrm{m}^{2}\right)\end{array}$ & 30 & $29,5 \pm 4,7$ & $28,7 \pm 4,5$ & $28,2 \pm 4,4$ & $0,8 \mathrm{~kg} / \mathrm{m}^{2}$ & $0,5 \mathrm{~kg} / \mathrm{m}^{2}$ \\
\hline PLT (\%) & 30 & $32,1 \pm 8,3$ & $30,8 \pm 7,7$ & $29,5 \pm 7,4$ & $1,3 \%$ & $1,3 \%$ \\
\hline
\end{tabular}

perubahan aktivitas hormon dan ditambah dengan aktivitas yang menurun dan mengakibatkan peningkatan berat badan, sehingga responden mengikuti program diet di My Meal Catering untuk menurunkan berat badan $^{14}$. Sebanyak 93,3\% responden tergolong pada tingkat pendidikan perguruan tinggi. Aktivitas fisik responden rata-rata tergolong pada aktivitas ringan yakni sebanyak $66,6 \%$. Hal tersebut disebabkan sebagian besar responden lebih banyak duduk saat bekerja, perpindahan dari satu tempat ke tempat lain menggunakan kendaaran dan responden tidak berolahraga di luar jam kantor.

Tabel 2 menunjukkan total kandungan energi dan zat gizi makro yang dikonsumsi klien diet south beach fase 1 yakni energi sekitar $1058 \mathrm{kkal} / \mathrm{hari}$, karbohidrat 123 gram/hari, protein 68,5 gram/hari dan lemak 42 gram/hari. Penyediaan makanan dibandingkan dengan Angka Kecukupan Gizi (AKG) berdasarkan usia dan jenis kelamin. ${ }^{11}$ Asupan energi dan karbohidrat masing-masing sebesar $100 \%$ dan lemak sebesar 90\% tergolong jauh dibawah kebutuhan responden seharusnya atau dikatakan inadekuat. Asupan protein sebesar $100 \%$ tergolong adekuat atau telah memenuhi kecukupan masing-masing klien.
Total kandungan energi dan zat gizi makro yang dikonsumsi klien diet south beach fase 2 yakni energi sekitar $1413 \mathrm{kkal} /$ hari, karbohdirat 132 gram/hari, protein 81 gram/hari dan lemak 41 gram/hari. Penyediaan makanan dibandingkan dengan Angka Kecukupan Gizi (AKG) berdasarkan usia dan jenis kelamin ${ }^{11}$. Asupan energi sebesar 93,3\%, karbohidrat sebesar $100 \%$ dan lemak sebesar 83,3\% tergolong jauh dibawah kebutuhan responden seharusnya atau dikatakan inadekuat. Asupan protein sebesar $100 \%$ tergolong adekuat atau telah memenuhi kecukupan masing-masing klien.

Tabel 3 menunjukkan bahwa indeks massa tubuh yang tergolong obesitas cenderung mengalami penurunan selama penerapan diet south beach. Sebelum mengikuti diet south beach, terdapat $63,3 \%$ yang mengalami obesitas. Jumlah ini menurun pada hari ke 14 diet south beach menjadi berturut-turut $60 \%$ responden. Pada hari ke 28 , persentase ini semakin menurun menjadi $53,3 \%$ responden.

Persentase lemak tubuh yang tergolong obesitas cenderung mengalami penurunan selama penerapan diet south beach. Sebelum mengikuti diet south beach, terdapat $66,6 \%$ responden yang mengalami obesitas. Jumlah ini menurun pada hari ke 14 diet south beach 
menjadi berturut-turut $63,3 \%$ responden. Pada hari ke 28, persentase ini semakin menurun menjadi $53,3 \%$ responden.

Tabel 4 menunjukkan bahwa terdapat perubahan BB, IMT dan PLT sebelum dan sesudah diet south beach pada hari ke 14 dan hari ke 28. Rata-rata perubahan BB sebelum dan sesudah diet pada hari ke 14 yakni sebesar 2,4 kg. Penurunan tersebut tidak sesuai dengan teori yang menyatakan bahwa penurunan berat badan fase 1 diet south beach yakni 4-7 $\mathrm{kg}^{7}$. Hal tersebut disebabkan penurunan berat badan secara drastis tidak dapat terjadi dalam waktu yang singkat. Menurut teori, penurunan berat badan sebaiknya dilakukan secara bertahap yakni 0,5-1 kg per minggu ${ }^{12}$. Perubahan berat badan hari ke 28 sebesar $1,4 \mathrm{~kg}$. Hal tersbeut sesuai dengan teori bahwa penurunan berat badan fase 2 diet SB yakni sebanyak 1/2-1 $\mathrm{kg} /$ minggu $^{7}$. Penelitian sebelumnya menunjukkan penurunan berat badan sebanyak 4,24 kg setelah menjalani diet rendah karbohidrat selama 2 minggu $^{10}$. Namun turunnya berat badan dapat disebabkan terjadinya pelepasan air dan deplesi glikogen pada dua minggu pertama ${ }^{15}$. Apabila berat badan turun, kemungkinan besar yakni lepasnya air sebesar $55-65 \%$ dan lemak 30 $40 \%{ }^{16}$.

Ketika asupan karbohidrat terbatas, tubuh menggunakan sebagian cadangan glikogen untuk memenuhi kebutuhan pemeliharaan glukosa darah. Cadangan glikogen dalam tubuh sekitar 70-100 gram yang disimpan dihati dan sekitar 400 gram di otot. Setiap gram glikogen terikat dengan 3 gram air. Sehingga apabila kehilangan cadangan glikogen maka akan diikuti dengan kehilangan air. Penurunan berat badan di awal karena pengurangan glikogen dari hati (5\% dari berat hati) dan otot ( $1 \%$ dari berat otot) ${ }^{9}$.

Rata-rata perubahan indeks massa tubuh responden sebelum dan sesudah diet hari ke 14 yakni sebesar $0,8 \mathrm{~kg} / \mathrm{m}^{2}$ dan hari ke 28 sebesar $0,5 \mathrm{~kg} / \mathrm{m}^{2}$. Penurunan indeks massa tubuh tergolong lebih rendah jika dibandingkan penelitian sebelumnya yakni sebesar $1,56 \mathrm{~kg} / \mathrm{m}^{2}{ }^{10}$. Terjadinya perubahan indeks massa tubuh dipengaruhi oleh perubahan berat badan. Indeks massa tubuh responden pada sebelum dan sesudah diet tidak mengalami perubahan dan masih tergolong dalam kategori obesitas. Hal tersebut dapat disebabkan karena responden meminta libur pengiriman catering, yang dapat mengakibatkan responden mengonsumsi makanan dari luar catering. Obesitas dapat memicu terjadinya penyakit degeneratif seperti diabetes mellitus, penyakit jantung koroner dan hipertensi ${ }^{17}$.

Rata-rata perubahan persentase lemak tubuh responden sebelum dan sesudah diet hari ke 14 yakni sebesar $1,3 \%$ dan hari ke 28 yakni sebesar $1,3 \%$. Perubahan persentase lemak tubuh tersebut tergolong sedikit lebih rendah apabila dibandingkan dengan penelitian sebelumnya yakni $1,83 \%{ }^{10}$. Penilaian status gizi melalui nilai persentase lemak tubuh mempunyai perbedaan standar antara pria dan wanita, masing-masing tergolong obesitas jika $\geq 25 \%$ dan $\geq 32 \%{ }^{18}$. Pada penelitian ini dari total keseluruhan responden PLT wanita sebesar 47\% dan 69,2\% responden pria tergolong obesitas.

Apabila ketersediaan karbohidrat dari glikogen hati dan asupan karbohidrat rendah dalam jangka pendek dapat menyebabkan tubuh mengoksidasi lemak yang kemudian dapat terjadi penurunan kadar lemak tubuh $^{9,19}$. Diperkirakan telah terjadi ketosis (pembentukan keton) pada responden penelitian karena tingginya protein dan rendahnya karbohidrat yang dikonsumsi. Sifat alami dari pembentukan badan keton akibat glukoneogenesis tidak hanya memberikan pengaruh terhadap penurunan BB, IMT namun juga terhadap penurunan PLT pada pemberian diet rendah karbohidrat ${ }^{16}$. Sintesis glukosa dari sumber zat non-karbohidrat, seperti asam amino dan gliserol dengan hasil sampingan berupa badan keton. Apabila pembentukan keton berlangsung dalam waktu lama maka dapat menyebabkan ketoasidosis ${ }^{8}$.

Penelitian ini memiliki kelemahan yaitu responden sering meminta off pengiriman catering, yang mengakibatkan klien mengonsumsi makanan diluar My Meal Catering. Hal tersebut dikhawatirkan mempengaruhi data perubahan berat badan karena klien tidak mengikuti diet secara teratur dan berturut-turut hingga program diet selesai. Recall dilakukan dua kali pada fase 1 dan fase 2 (satu kali pada setiap fase) 
sehingga tidak dapat menggambarkan asupan makanan karena data yang diperoleh kurang representatif untuk menggambarkan kebiasaan individu.

\section{KESIMPULAN}

Pemberian diet south beach dapat menurunkan BB, IMT dan PLT klien My Meal Catering pada hari ke 14 dan dapat terus menurun hingga hari ke 28. Asupan energi yang inadekuat juga dapat membantu dalam menurunkan BB dan IMT namun tidak menurunkan PLT responden. Responden diharapkan dapat mengenal pola makan sehat dan menerapkan serta mengadosinya sebagai haya hidup seterusnya, tahap demi tahap. Sehingga responden mendapatkan serta mempertahankan berat badan normal.

\section{ACKNOWLEDGEMENT}

Peneliti mengucapkan terima kasih kepada pemilik my meal catering yang telah memberikan izin untuk dijadikan tempat penelitian sehingga penelitian ini dapat terlaksana dan Costumer My Meal Catering telah meluangkan waktu membantu penelitian ini.

\section{REFERENSI}

1. Suwandani, S. Diet Rendah Kalori dan Metformin Menurunkan Berat Badan Lebih Tinggi Daripada Diet Rendah Kalori atau Metformin Saja Pada Pasien Obesitas. (Universitas Udayana, 2010).

2. WHO. Top 10 Causes of Death. (2011). Available at: www.who.int/mediacentre/factsheets/fs 310/en. (Accessed: 16th May 2017)

3. Tchernof, A. \& Despres, J.-P. Pathophysiology of Human Visceral Obesity: An Update. Physiol. Rev. 93, 359-404 (2013).

4. Dinas Kesehatan Kota Surabaya. Profil Dinas Kesehatan Kota Surabaya 2014. (2014).

5. Dinas Kesehatan Kota Surabaya. Profil Kesehatan Kota Surabaya, tahun 2015. (2015). Available at: http://www.depkes.go.id/resources/dow nload/profil/PROFIL_KAB_KOTA_2015/35
78_Jatim_Kota_Surabaya_2015.

(Accessed: 18th May 2017)

6. Misnadiarly. Obesitas sebagai Faktor Resiko Beberapa Penyakit. (Pustaka Obor Populer, 2007).

7. VitaHealth. Panduan Praktis Melakukan South Beach Diet. (PT Gramedia Pustaka Utama, 2006).

8. Chalasani, S. \& Fischer, J. South Beach Diet associated ketoacidosis: A case report. J. Med. Case Rep. 2, 1-3 (2008).

9. Adam-Perrot, A., Clifton, P. \& Brouns, F. Low-carbohydrate diets: nutritional and physiological aspects. Obes. Rev. 7, 49-58 (2006).

10. Ramadhani, T. . Pengaruh Pemberian Diet Rendah Karbohidrat Terhadap Perubahan Berat Badan, Indeks Massa Tubuh dan Persentase Lemak Tubuh Di Catering SlimGourmet. (Universitas Indonesia, 2012).

11. Depkes. Permenkes No. 75 tahun 2013 tentang AKG 2013. 10 (2013).

12. Almatsier, S. Penuntun Diet. (PT.Gramedia Pustaka Utama, 2004).

13. Bestiana, D. Citra Tubuh dan Konsep Ideal Mahasiswa FISIP Universitas Airlangga Surabaya. (Universitas Airlangga, 2012).

14. Brown, J. . Nutrition Through the Life Cycle. (Thomson Wadworth, 2008).

15. Löfgren, P. et al. Major gender differences in the lipolytic capacity of abdominal subcutaneous fat cells in obesity observed before and after longterm weight reduction. J. Clin. Endocrinol. Metab. 87, 764-771 (2002).

16. Nix, S. Williams' Basic Nutrition \& Diet Therapy. (Elsevier Mosby, 2004).

17. Lebowitz, J. The Effect of Obesity and Overweight on Health. (Parmacist, 2012).

18. Gibson, R. S. Principles of nutritional assessment. (Oxford University Press, 2005).

19. Dewi, P. K., Akbar, I. B. \& Yulianti, A. B. Hubungan Kebugaran Jasmani Dan Lemak Tubuh Pada Kelompok Senam Dan Kelompok Tidak Senam. in Prosiding Penelitian Sivitas Akademika Unisba (Kesehatan) 1016-1022 (2014). 